\title{
Metode FUZZY AHP untuk Pemilihan Ketua OSIS pada SMA N 1 Jogonalan Klaten
}

\author{
FUZZY AHP Method for the Election of Student Council Presiden \\ at SMA N 1 Jogonalan Klaten
}

\author{
Yuli Astuti*1, Alif Safrudin ${ }^{2}$ \\ 1,2 Manajemen Informatika STMIK AMIKOM Yogyakarta \\ E-mail: ${ }^{* 1}$ yuli@amikom.ac.id, ${ }^{2}$ alief.safrudin@gmail.com
}

\begin{abstract}
Abstrak
Organisasasi Intra Sekolah atau OSIS sudah sering didengar ketika masih berada di bangku sekolah. Dimana pada organisasi tersebut terdapat banyak tujuan sehingga menimbulkan antusias siswa siswi menjadi ketua osis. Penentuan ketua OSIS yang tepat merupakan salah satu faktor penting dalam menjamin kesuksesan organisasi tersebut. Untuk itu pada penelitian ini akan dibuat sistem terkomputerisasi yang dapat digunakan untuk membantu memberi penilaian yang lebih objective dalam pengambilan keputusan yang mampu melakukan penilaian kelayakan menjadi ketua OSIS. Hasil yang didapatkan berupa peringkat, dimana yang memiliki nilai tertinggi akan menjadi ketua OSIS dengan kriteria intelegensia, kepribadian, sikap, dan manajerial. Penilaian tingkat konsistensi menggunakan metode Fuzzy-AHP yang dilakukan pada setiap level struktur hirarki mampu mengakomodir ketidak konsistenan dalam penilaian yang pada akhirnya, akan diperoleh ketua OSIS terbaik dan dapat melakukan perhitungan nilai Sintesis (Si), Nilai Vektor (V), Nilai Ordinat Defuzzifikasi (d'), Normalisasi Bobot Vektor (W), Analisa dan Pemobobotan. Sehingga, setelah dilakukan perhitungan tersebut didapatkan perankingan dari alternatif calon OSIS. Hasil dari pembahasan ini bahwa Mustofa mendapatkan nilai akhir 29.342, Danang mendapatkan nilai akhir 29.244, Fajar mendapatkan nilai akhir 29.093 dan Agatha mendapatkan nilai akhir 27.656. Dari data-data tersebut dapat disimpulkan bahwa Mustofa yang terpilih menjadi ketua OSIS dengan nilai tertinggi yaitu 29.342.
\end{abstract}

Kata Kunci - OSIS, Fuzzy-AHP, Sistesis, Vektor, Defuzzifikasi

\begin{abstract}
Students' Union or usually called the student council often familiar in school. Where the organization there is interest to students became student council president. Determination of the student council president is important factor organization to success. This research will make a computerized system that can be used to help provide an objective assessment of the decision to conduct a feasibility assessment into student council president.The result is rank which has the highest score will be the student council president with intelligence criteria, personality, attitude, and managerial. The level assessment of consistency using Fuzzy-AHP conducted hierarchy structure level to accommodate inconsistencies in the valuation, which in turn, will obtain a student council president the best and can be calculate of Synthesis Value (Si), Vector Value (V), Ordinate Defuzzification Value (d '), Normalized Vector Weights (W), Analysis and Weighting. After the calculation obtained a rank of the alternative candidates for the council. The results are Mostopha get the final value 29342, Danang get the final value 29 244, Fajar get the final value 29093 and 27656 Agatha get the final value. Data established that Mustafa who was elected student council president with the highest score is 29342.
\end{abstract}

Keywords — OSIS, Fuzzy-AHP, Sistesis, Vector, Defuzzifikasi 


\section{PENDAHULUAN}

OSIS siswa merupakan kegiatan yang wajib dilakukan setiap tahun, pemilihan ketua OSIS dilakukan dengan memberi penilaian terhadap siswa. Penilaian tersebut dilakukan untuk mengetahui peringkat siswa untuk dapat menjadi ketua OSIS karena OSIS menjadi salah satu organisasi yang sering diberi tanggung jawab oleh pihak sekolah untuk merencanakan kegiatan.

SMA Negeri 1 Jogonalan merupakan sekolah yang terdapat di Klaten yang selalu berupaya dalam peningkatan mutu internal secara berkelanjutan agar dapat bersaing dengan sekolah yang lain. Salah satu upaya yang sudah dilakukan adalah melakukan pemilihan ketua OSIS terhadap siswa siswinya dan pemilihan dilakukan setiap akhir semester ganjil. Proses penilaian tersebut masih dilakukan secara manual dan diimplementasikan dalam bentuk tertulis, sehingga membutuhkan waktu yang cukup lama untuk melakukan pengolahan data. Untuk itu akan dibuat sistem terkomputerisasi yang dapat digunakan untuk membantu memberi penilaian yang lebih objective dalam pengambilan keputusan yang mampu melakukan penilaian kelayakan menjadi ketua OSIS. Setelah penilaian selesai dilakukan, maka akan di dapatkan hasil berupa peringkat, dimana yang memiliki nilai tertinggi akan menjadi ketua OSIS.

Pada penelitian ini metode yang digunakan untuk pengambilan keputusan adalah menggunakan metode Fuzzy Analytic Hierarchy Process (FAHP). Konsep metode FAHP adalah menutupi kelemahan yang terdapat pada AHP yaitu permasalahan terhadap kriteria yang memiliki sifat subjektif lebih banyak, sehingga keputusan-keputusan yang diambil bisa lebih efektif.

Decission Support System (DSS) atau Sistem pendukung keputusan sebagai sekumpulan prosedur berbasis model untuk data pemrosesan dan penilaian guna membantu para manajer mengambil keputusan [1]. Beliau menyatakan bahwa untuk sukses, sistem tersebut haruslah sederhana, cepat, mudah dikontrol, adaptif, lengkap dengan isu penting, dan mudah berkomunikasi. DSS biasanya dibangun untuk mendukung solusi terhadap suatu masalah atau untuk mengevaluasi suatu peluang dengan pendekatan atau metodologi untuk mendukung pengambilan keputusan. Aplikasi DSS tersebut menggunakan CBIS (Computer Based Information System) yang fleksibel, interaktif, dan dapat diadaptasi, yang dikembangkan untuk mendukung solusi untuk masalah manajemen spesifik yang tidak terstruktur [2].

Fuzzy Analytic Hierarchy Process (FAHP) merupakan metode analitik yang dikembangkan dari metode AHP. Penggunaan AHP dalam permasalahan Multi Criteria Decision Making (MCDM) sering dikritisi karena kurang mampunya pendekatan AHP ini untuk mengatasi faktor ketidakpresisian yang dialami oleh pengambil keputusan ketika harus memberikan nilai yang pasti dalam matriks perbandingan berpasangan. Oleh karena itu, untuk mengatasi permasalahan yang ada pada AHP dikembangkan suatu metode yang disebut Fuzzy AHP.

Penentuan derajat keanggotaan F-AHP menggunakan fungsi keanggotaan Segitiga (Tringular Fuzzy Number / TFN). Fungsi keanggotaan segitiga merupakan gabungan antara dua garis (linear) [3]. Grafik fungsi keanggotaan segitiga digambarkan dalam bentuk kurva segitiga seperti terlihat pada Gambar 1.

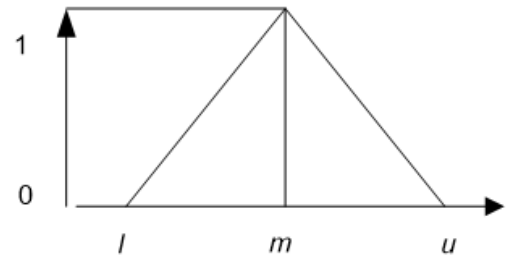

Gambar 1. Fungsi Keanggotaan Segitiga [1].

$$
\text { Dimana } \mu_{A}=\left\{\begin{array}{l}
\frac{\mathrm{x}-1}{m-1}, l \leq x \leq m \\
\frac{\mathrm{u}-\mathrm{x}}{\mathrm{u}-\mathrm{m}}, m \leq x \leq u \\
0, \mathrm{x} \leq l \text { dan } x \geq u
\end{array}\right.
$$


Bilangan Tringular Fuzzy Number (TFN) merupakan teori himpunan fuzzy membantu dalam pengukuran yang berhubungan denga penilaian subjektif manusia memakai bahasa atau linguistik. Inti dari fuzzy AHP terletak pada perbandingan berpasangan yang digambarkan dengan skala rasio yang berhubugan dengan skala fuzzy. Bilangan TFN disimbolkan dengan $M$.

Pada model AHP orisinil, pairwise comparison menggunakan skala 1 - 9 [4]. Dengan mentransformasi Triangular Fuzzy Number terhadap skala AHP maka skala yang digunakan adalah seperti pada Tabel 1.

Tabel 1. Skala Nilai Fuzzy Segitiga (Chang,1996)

\begin{tabular}{|c|c|c|c|}
\hline $\begin{array}{c}\text { Intensitas } \\
\text { Kepentingan } \\
\text { AHP }\end{array}$ & Himpunan Linguistik & $\begin{array}{c}\text { Triangular } \\
\text { Fuzzy } \\
\text { Number } \\
\text { (TFN) } \\
\end{array}$ & $\begin{array}{l}\text { Reciprocal } \\
\text { (Kebalikan) }\end{array}$ \\
\hline 1 & Perbandingan elemen yang sama (Just Equal) & $(1,1,1)$ & $(1,1,1)$ \\
\hline 2 & Pertengahan (Intermediate) & $\begin{array}{c}(1 / 2,1 \\
3 / 2)\end{array}$ & $(2 / 3,1,2)$ \\
\hline 3 & $\begin{array}{l}\text { Elemen satu cukup perting dari yang lainnya } \\
\text { (moderately important) }\end{array}$ & $(1,3 / 2,2)$ & $(1 / 2,2 / 3,1)$ \\
\hline 4 & $\begin{array}{l}\text { Pertengahan (Intermediate) elemen satu lebih } \\
\text { cukup penting dari yang lainnya) }\end{array}$ & $\begin{array}{c}(3 / 2,2, \\
5 / 2)\end{array}$ & $(2 / 5,1 / 2,2 / 3)$ \\
\hline 5 & $\begin{array}{l}\text { Elemen satu kuat pentingnya dari yang lain } \\
\text { (Strongly Important) }\end{array}$ & $(2,5 / 2,3)$ & $(1 / 3,2 / 5,1 / 2)$ \\
\hline 6 & Pertengahan (Intermediate) & $\begin{array}{c}(5 / 2,3, \\
7 / 2)\end{array}$ & $(2 / 7,1 / 3,2 / 5)$ \\
\hline 7 & $\begin{array}{l}\text { Elemen satu lebih kuat pentingnya dari yang } \\
\text { lain (Very Strong) }\end{array}$ & $(3,7 / 2,4)$ & $(1 / 4,2 / 7,1 / 3)$ \\
\hline 8 & Pertengahan (Intermediate) & $\begin{array}{c}(7 / 2,4, \\
9 / 2)\end{array}$ & $(2,9,1 / 4,2 / 7)$ \\
\hline 9 & $\begin{array}{l}\text { Elemen satu mutlak lebih penting dari yang } \\
\text { lainnya (Extremely Strong) }\end{array}$ & $\begin{array}{c}(4,9 / 2 \\
9 / 2)\end{array}$ & $(2 / 9,2 / 9,1 / 4)$ \\
\hline
\end{tabular}

Aturan-aturan operasi aritmatika Tringular Fuzzy Number yang umum digunakan. Misalkan terdapat 2 TFN yaitu $M_{1}=\left(l_{1}, m_{1}, u_{1}\right)$ dan $M_{2}=\left(l_{2}, m_{2}, u_{2}\right)$, operasi aritmatika Tringular Fuzzy Number (TFN) adalah sebagi berikut [4]:

$$
\begin{aligned}
& \mathrm{M}_{1}+\mathrm{M}_{2}=\left(\mathrm{l}_{1}+\mathrm{l}_{2}, \mathrm{~m}_{1}+\mathrm{m}_{2}, \mathrm{u}_{1}+\mathrm{u}_{2}\right) \\
& \mathrm{M}_{1}-\mathrm{M}_{2}=\left(\mathrm{l}_{1}-\mathrm{u}_{2}, \mathrm{~m}_{1}-\mathrm{m}_{2}, \mathrm{u}_{1}-\mathrm{l}_{2}\right) \\
& \mathrm{M}_{1} \times \mathrm{M}_{2}=\left(\mathrm{l}_{1} . \mathrm{l}_{2}, \mathrm{~m}_{1} \cdot \mathrm{m}_{2}, \mathrm{u}_{1} . \mathrm{u}_{2}\right) \\
& \mathrm{M}^{-1}=\left(1 / u_{1}, 1 / m_{1}, 1 / l_{1}\right) \\
& \frac{M_{1}}{M_{2}}=\left(l_{1} / u_{2}, m_{1} / m_{2}, u_{1} / l_{2}\right)
\end{aligned}
$$

\section{METODE PENELITIAN}

Metode yang digunakan pada penelitian ini yaitu:

\subsection{Mengumpulkan Data}

Dalam pengumpulan data peneliti melakukan wawancara dengan MPK, dan ketua OSIS. Wawancara yang dilakukan berisi pertanyaan-pertanyaan yang berkaitan dengan data-data yang dibutuhkan dalam proses pengembangan sistem seperti daftar kriteria yang dibutuhkan dalam penilaian pemilihan ketua OSIS. 


\subsection{Menentukan Kriteria}

Dari hasil pengambilan maka dapat ditentukan kriteria untuk sistem pendukung keputusan ini yaitu pengetahuan, konsep hitung, konsep logis, percaya diri, stabilitas emosi, komunikasi, tanggung jawab, disiplin, kerja nyata, visi misi, pengorganisasian, kepemimpinan. Kemudian, kriteria di masukkan ke dalam subkriteria dengan kriteria intelegensia, kepribadian, sikap, dan manajerial.

\subsection{Daftar Alternatif}

Alternatif adalah data-data yang dibandingkan. Dalam penelitian ini setiap calon ketua diseleksi melalui tes yang telah diberikan oleh anggota MPK SMA N 1 Jogonalan. Tes diberikan berupa tes tertulis dan tes wawancara. Dari hasil tes akan dilakukan penilaian terhadap calon OSIS dimana parameter penilaian tersebut diambil dari kriteria yang telah diberikan. Berikut daftar alternatif.

\subsection{Membuat Struktur Hirarki}

Pada tahap ini dibuat struktur hirarki dengan goal ketua OSIS dengan kriteria intelegensia dengan sub kriteria pengetahuan, konsep hitung dan konsep logis, kriteri kepribadian dengan sub kriteria percaya diri, stabilitas emosi dan komunikasi, kriteri sikap dengan sub kriteria tanggung jawab, disiplin dan kerja nyata serta kriteri manajerial dengan sub kriteria visi misi, keorganisasian dan kepemimpinan dan menentukan alternatif terhadap calon ketua OSIS yaitu Agatha, Danang P, Fajar Andika dan Mustofa N.

\subsection{Perhitungan AHP}

Langkah-langkah metode AHP dalam melakukan perhitungan nilai rasio konsistensi matriks perbandingn berpasangan diatas dapat dijelaskan sebagai berikut [2]:

a. Menjumlahkan nilai-nilai dari setiap kolom pada matriks.

b. Membagi setiap nilai dari total kolom yang bersangkutan untuk memperoleh normalisasi matriks.

c. Menghitung rata-rata dari hasil normalisasi matriks untuk memperoleh vektor prioritas.

d. Mengalikan nilai-nilai matriks dengan nilai rata-rata matriks yang diperoleh untuk memperoleh vektor jumlah bobot dengan menjumlahkan setiap hasil normalisasi.

e. Membagi nilai vektor jumlah bobot dengan vektor prioritas, kemudian dijumlahkan hasil pembagian tersebut.

f. Selanjutnya mencari nilai $\lambda$ maks dengan menggunakan persamaan:

$$
\lambda \text { maks }=\frac{\sum a}{n-1}
$$

g. Menghitung indeks konsistensi (consistency index/CI) dengan rumus:

$$
\mathrm{CI}=\frac{\lambda-\text { nmaks }}{n-1}
$$

h. Menghitung konsistensi rasio (consistency index/CI) dengan rumus:

$$
\mathrm{CR}=\frac{\mathrm{CI}}{\mathrm{IR}}
$$


Tabel Random Index (RI) untuk matriks berukuran 1 sampai 15:

Tabel 2. Random Index (RI)

\begin{tabular}{|c|c|c|c|c|c|c|c|c|c|c|c|c|c|c|}
\hline $\mathbf{N}$ & $\mathbf{1 , 2}$ & $\mathbf{3}$ & $\mathbf{4}$ & $\mathbf{5}$ & $\mathbf{6}$ & $\mathbf{7}$ & $\mathbf{8}$ & $\mathbf{9}$ & $\mathbf{1 0}$ & $\mathbf{1 1}$ & $\mathbf{1 2}$ & $\mathbf{1 3}$ & $\mathbf{1 4}$ & $\mathbf{1 5}$ \\
\hline $\mathrm{RI}$ & 0,00 & 0,58 & 0,90 & 1,12 & 1,24 & 1,32 & 1,41 & 1,45 & 1,49 & 1,51 & 1,48 & 1,56 & 1,57 & 1,59 \\
\hline
\end{tabular}

Tabel 3. Nilai Intensitas AHP [3]

\begin{tabular}{|c|l|}
\hline $\begin{array}{c}\text { Intensitas dari } \\
\text { kepentingan pada } \\
\text { skala absolut }\end{array}$ & \multicolumn{1}{|c|}{ Definisi } \\
\hline 1 & Sama penting dengan \\
\hline 2 & Mendekati sedikit lebih penting dari \\
\hline 3 & Sedikit lebih penting dari \\
\hline 4 & Mendekati lebih penting dari \\
\hline 5 & Lebih penting dari \\
\hline 6 & Mendekati sangat penting dari \\
\hline 7 & Sangat penting dari \\
\hline 8 & Mendekati mutlak dari \\
\hline 9 & Mutlak sangat penting dari \\
\hline
\end{tabular}

\subsection{Perhitungan FAHP}

Langkah-langkah Perhitungan FAHP dapat dijelaskan sebagai berikut [5]:

a. Membuat struktur hirarki masalah yang akan diselesaikan dan menentukan perbandingan matriks berpasangan antar kriteria dengan skala TFN (tabel 1)

b. Menentukan nilai sintesi fuzzy (Si) prioritas dengan rumus,

$$
S_{i}=\sum_{j=i}^{m} M_{i}^{j} \times\left[\sum_{i=1}^{n} \sum_{j=1}^{m} M_{i}^{j}\right]^{-1}
$$

Dimana:

$\sum_{j=1}^{m} M_{i}^{j}=\sum_{j=1}^{m} l j, \sum_{j=1}^{m} m j, \sum_{j=1}^{m} u j$

Sedangkan

$$
\frac{1}{\sum_{j=1}^{n} \sum_{j=1}^{m} M_{i}^{j}}=\frac{1}{\sum_{i=1}^{n} u i, \sum_{i=1}^{n} m i, \sum_{i=1}^{n} l i}
$$


Citec Journal, Vol. 4, No. 1, November 2016 - Januari 2017

c. Menentukan Nilai Vektor (V) dan Nilai Ordinat Defuzzifikasi (d')

Jika hasil yang diperoleh pada setiap matrik fuzzy,

$M_{2} \geq M_{1}\left(M_{2}=\left(l_{2}, m_{2}, u_{2}\right)\right.$ dan $M_{2}=\left(l_{1}, m_{1}, u_{1}\right)$ maka nilai vector dapat dirumuskan sebagai berikut:

$V\left(M_{2} \geq M_{1}\right)=\sup \left[\min \left(\mu M_{1}(x), \min \left(\mu M_{2}(y)\right)\right)\right]$

atau sama dengan grafik pada gambar berikut:

$$
V\left(M_{2} \geq M_{1}\right)=\left\{\begin{array}{c}
1, \quad \text { if } m_{2} \geq m_{1}, \\
0, \quad \text { if } l_{i} \geq \mu_{2} \\
\frac{l_{1}-u_{2}}{\left(m_{2}-u_{2}\right)-\left(m_{1}-l_{1}\right)}
\end{array}\right.
$$

Jika hasil nilai fuzzy lebih besar dari $\mathrm{k}, \mathrm{M}_{\mathrm{i}}(\mathrm{i}=1,2, \mathrm{k})$ maka nilai vektor dapat didefinisikan sebagai berikut:

$V\left(M \geq M_{1}, M_{2}, \ldots \ldots ., M_{k}\right)=V\left(M \geq M_{1}\right)$ dan $V\left(M \geq M_{2}\right)$ dan

$V\left(M \geq M_{k}\right)=\min V\left(M \geq M_{i}\right)$.

Asumsikan bahwa,

$d^{\prime}(A i)=\min V(S i \geq S k)$

Untuk $\mathrm{k}=1,2, \ldots ., \mathrm{n} ; \mathrm{k} \neq \mathrm{i}$, maka diperoleh nilai bobot vector

$W^{\prime}=\left(d^{\prime}\left(A_{1}\right), d^{\prime}\left(A_{2}\right), \ldots, d^{\prime}\left(A_{n}\right)\right)^{\mathrm{T}}$

Disana $A_{i}=1,2, \ldots, n$ adalah n element keputusan.

d. Normalisasi nilai bobot vector fuzzy (W)

Setelah dilakukan normalisasi dari persamaan (7) maka nilai bobot vector yang ternormalisasi adalah seperti rumus berikut:

$$
W=\left(d\left(A_{1}\right), d\left(A_{2}\right), \ldots, d\left(A_{n}\right)\right)^{T}
$$

Dimana W adalah bilangan non fuzzy.

Penelitian serupa pernah dilakukan sebelumnya yaitu tentang perancangan sistem pendukung keputusan penerimaan calon pengurus osis menggunakan metode composite performance index (CPI) yang dapat digunakan untuk membantu seleksi penerimaan OSIS yang diterpakan di SMPN 1 Kesamben dengan mudah dan efisien [6].

Sedangkan penelitian yang dilakukan oleh Elveny (2014), tentang analisis metode Fuzzy Analytic Hierarchy (FAHP) dalam menentukan posisi jabatan yang menggunakan penilaian dalam interval, sehingga data kualitatif dapat memberikan penilaian yang lebih objektif [3].

Dan penelitian tentang perancangan sistem pendukung keputusan (SPK) pemilihan karyawan terbaik menggunakan metode Fuzzy AHP (F-AHP) yang mendekati cara penilaian yang sebenarnya [5]. 


\section{HASIL DAN PEMBAHASAN}

\subsection{Menentukan Kriteria}

Daftar kriteria dijelaskan pada Tabel 4.

Tabel 4. Daftar Kriteria dan Sub Kriteria

\begin{tabular}{|c|c|c|c|c|}
\hline No. & Kriteria & Nama Kriteria & Kode Sub-Kriteria & Nama Sub-Kriteria \\
\hline \multirow{3}{*}{1.} & \multirow{3}{*}{ K1 } & \multirow{3}{*}{ Intelegensia } & S01 & Pengetahuan \\
\hline & & & S02 & Konsep Hitung \\
\hline & & & S03 & Konsep Logis \\
\hline \multirow{3}{*}{2.} & \multirow{3}{*}{ K2 } & \multirow{3}{*}{ Kepribadian } & S04 & Percaya Diri \\
\hline & & & S05 & Stabilitas Emosi \\
\hline & & & S06 & Komunikasi \\
\hline \multirow{3}{*}{3.} & \multirow{3}{*}{ K3 } & \multirow{3}{*}{ Sikap } & S07 & Tanggung Jawab \\
\hline & & & S08 & Disiplin \\
\hline & & & S09 & Kerja Nyata \\
\hline \multirow{3}{*}{4.} & \multirow{3}{*}{ K4 } & \multirow{3}{*}{ Manajerial } & S10 & Visi Misi \\
\hline & & & S11 & Pengorganisasian \\
\hline & & & $\mathrm{S} 12$ & Kepemimpinan \\
\hline
\end{tabular}

\subsection{Membuat Alternatif}

Data alternatif dapat dilihat pada Tabel 5.

Tabel 5. Data Alternatif

\begin{tabular}{|c|l|c|}
\hline & \multicolumn{1}{|c|}{ Alternatif } & Kode \\
\hline 1. & Agatha & A01 \\
\hline 2. & Danang P & A02 \\
\hline 3. & Fajar Andika & A03 \\
\hline 4. & Mustofa N & A04 \\
\hline
\end{tabular}

3.3. Membuat Struktur Hierarki

Gambar struktur hirarki bisa dilihat pada Gambar 2.

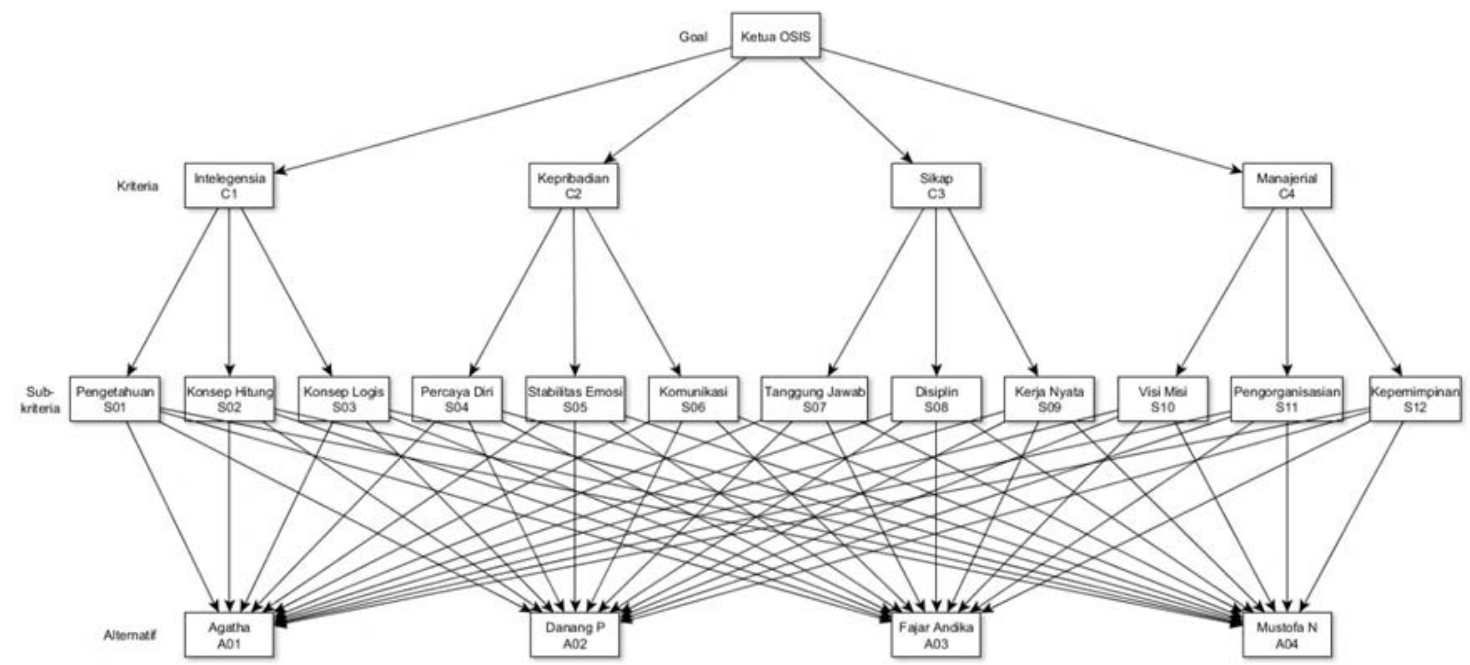

Gambar 2.Struktur Hirarki Pemilihan Ketua OSIS[3] 
Citec Journal, Vol. 4, No. 1, November 2016 - Januari 2017

ISSN: 2460-4259

\subsection{Perhitungan dengan AHP}

\subsubsection{Membuat Kode Kriteria}

Tabel 6. Kode Kriteria

\begin{tabular}{|c|c|}
\hline Kode Kriteria & Nama Kriteria \\
\hline C1 & Intelegensia \\
\hline C2 & Kepribadian \\
\hline C3 & Sikap \\
\hline C4 & Manajerial \\
\hline
\end{tabular}

\subsubsection{Perhitungan Bobot Kriteria}

Membandingkan data antar kriteria dalam bentuk matriks berpasangan dengan menggunakan skala intensitas kepentingan AHP.

Tabel 7. Perbandingan Matriks Berpasangan AHP

\begin{tabular}{|c|c|c|c|c|}
\hline & C1 & C2 & C3 & C4 \\
\hline C1 & 1 & 2 & 4 & 4 \\
\hline C2 & 0.5 & 1 & 3 & 3 \\
\hline C3 & 0.25 & 0.333 & 1 & 2 \\
\hline C4 & 0.25 & 0.333 & 0.5 & 1 \\
\hline
\end{tabular}

\subsubsection{Perhitungan Bobot Prioritas}

Selanjutnya menghitung nilai bobot prioritas yaitu nilai rata-rata dengan cara menjumlahkan nilia-nilai dari setiap baris dan membaginya dengan banyak elemen krteria.

Tabel 8. Nilai Bobot Prioritas

\begin{tabular}{|l|c|c|c|c|c|c|}
\hline & C1 & C2 & C3 & C4 & Bobot Prioritas & CM \\
\hline C1 & 0.5 & 0.545 & 0.471 & 0.4 & 0.479 & 4.123 \\
\hline C2 & 0.25 & 0.273 & 0.353 & 0.3 & 0.294 & 4.133 \\
\hline C3 & 0.125 & 0.091 & 0.118 & 0.2 & 0.133 & 4.037 \\
\hline C4 & 0.125 & 0.091 & 0.059 & 0.1 & 0.094 & 4.036 \\
\hline
\end{tabular}

Setelah diperoleh prioritas kriterianya, maka dihitung nilai lamda maksimum ( $\lambda$ maks) atau eigenvalue, yaitu menjumlahkan hasil perkalian bobot prioritas dengan jumlah kolom dengan persamaan.

\subsubsection{Mencari Nilai CI}

Kemudian langkah selanjutnya adalah mencari nilai CI dengan persamaan.

$$
\begin{aligned}
\mathrm{CI} & =(4.082-4) /(4-1) \\
& =0.027
\end{aligned}
$$

\subsubsection{Mencari Nilai $C R$} Persamaan.

Setelah Didapatkan Nilai CI Yaitu Menghitung Nilai CR Dengan Menggunakan

$$
\begin{aligned}
\mathrm{CR} & =0.027 / 0.91 \\
& =0.03 \text { (konsisten) }
\end{aligned}
$$


3.4.6. Membandingkan Data Antar Subkriteria Dalam Bentuk Matriks Berpasangan

Tabel 9. Data Antar Subkriteria

\begin{tabular}{|c|c|c|c|}
\hline Kode & Kode Kriteria & Nama Kriteria & Nama Sub Kriteria \\
\hline S01 & C1 & Intelegensia & Pengetahuan \\
\hline S02 & C1 & Intelegensia & Konsep Hitung \\
\hline S03 & C1 & Intelegensia & Konsep Logis \\
\hline S04 & C2 & Kepribadian & Percaya Diri \\
\hline S05 & C2 & Kepribadian & Stabilitas Emosi \\
\hline S06 & C2 & Kepribadian & Komnikasi \\
\hline S07 & C3 & Sikap & Tanggung Jawab \\
\hline S08 & C3 & Sikap & Disiplin \\
\hline S09 & C3 & Sikap & Kerja Nyata \\
\hline S10 & C4 & Manajerial & Visi Misi \\
\hline S11 & C4 & Manajerial & Pengorganisasian \\
\hline S12 & C4 & Manajerial & Kepemimpinan \\
\hline
\end{tabular}

a. Matriks Berpasangan Subkriteria Intelegensia

Tabel 10. Matriks Berpasangan Subkriteria Intelegensia

\begin{tabular}{|c|c|c|c|}
\hline & S01 & S02 & S03 \\
\hline S01 & 1 & 2 & 3 \\
\hline S02 & 0.5 & 1 & 2 \\
\hline S03 & 0.333 & 0.5 & 1 \\
\hline Total & $\mathbf{1 . 8 3 3}$ & $\mathbf{3 . 5}$ & $\mathbf{8 . 5}$ \\
\hline
\end{tabular}

b. Menghitung nilai bobot Prioritas (Intelegensia)

Tabel 11. Nilai Bobot Prioritas

\begin{tabular}{|c|c|c|c|c|c|}
\hline & S01 & S02 & S03 & Bobot Prioritas & CM \\
\hline S01 & 0,545455 & 0,571429 & 0,5 & 0,538961 & 3,014726 \\
\hline S02 & 0,272727 & 0,285714 & 0,333333 & 0,297258 & 3,008495 \\
\hline S03 & 0,181818 & 0,142857 & 0,166667 & 0,163781 & 3,004405 \\
\hline & $\mathbf{1}$ & $\mathbf{1}$ & $\mathbf{1}$ & $\mathbf{1}$ & \\
\hline
\end{tabular}

$$
\begin{aligned}
\mathrm{CI} & =(\lambda \text { maks-n) } /(\mathrm{n}-1) \\
& =(3.009-3) /(3-1) \\
& =0.005 \\
\mathrm{RI} & =0.9 \\
\mathrm{CR} & =\mathrm{CI} / \mathrm{RI} \\
& =0.005 / 0.9 \\
& =0.008 \text { (konsisten) }
\end{aligned}
$$


Citec Journal, Vol. 4, No. 1, November 2016 - Januari 2017

c. Matriks berpasangan subkriteria Kepribadian

Tabel 12. Matriks Berpasangan Subkriteria Kepribadian

\begin{tabular}{|c|c|c|c|}
\hline & S04 & S05 & S06 \\
\hline S04 & 1 & 3 & 4 \\
\hline S05 & 0,333333 & 1 & 3 \\
\hline S06 & 0,25 & 0,333333 & 1 \\
\hline Total & $\mathbf{1 , 5 8 3 3 3 3}$ & $\mathbf{4 , 3 3 3 3 3 3}$ & $\mathbf{8}$ \\
\hline
\end{tabular}

d. Menghitung nilai bobot Prioritas(kepribadian)

Tabel 13. Nilai Bobot Prioritas

\begin{tabular}{|l|c|c|c|c|c|}
\hline & S04 & S05 & S06 & Bobot Prioritas & CM \\
\hline S04 & 0,631579 & 0,692308 & 0,5 & 0,607962 & 3,131798 \\
\hline S05 & 0,210526 & 0,230769 & 0,375 & 0,272099 & 3,067163 \\
\hline S06 & 0,157895 & 0,076923 & 0,125 & 0,119939 & 3,023441 \\
\hline \multicolumn{7}{|c|}{} & $\mathbf{1}$ & $\mathbf{1}$ & $\mathbf{1}$ & $\mathbf{1}$ & \\
\hline
\end{tabular}

CI $=(\lambda$ maks-n) $/(\mathrm{n}-1)$

$=(4.014-3) /(3-1)$

$=0.005$

$\mathrm{RI}=0.9$

$\mathrm{CR}=\mathrm{CI} / \mathrm{RI}$

$=0.005 / 0.9$

$=0.008$ (konsisten)

e. Matriks berpasangan Subkriteria Sikap

Tabel 14. Matriks Berpasangan Subkriteria Sikap

\begin{tabular}{|c|c|c|c|}
\hline & S07 & S08 & S09 \\
\hline S07 & 1 & 3 & 5 \\
\hline S08 & 0,333333 & 1 & 1 \\
\hline S09 & 0,2 & 1 & 1 \\
\hline Total & $\mathbf{1 , 5 3 3 3 3 3}$ & $\mathbf{5}$ & $\mathbf{7}$ \\
\hline
\end{tabular}

f. Menghitung nilai bobot prioritas (Sikap)

Tebel 15. Nilai Bobot Prioritas

\begin{tabular}{|c|c|c|c|c|c|}
\hline & S07 & S08 & S09 & Bobot Prioritas & CM \\
\hline S07 & 0,652174 & 0,6 & 0,714286 & 0,655487 & 3,058117 \\
\hline S08 & 0,217391 & 0,2 & 0,142857 & 0,186749 & 3,014782 \\
\hline S09 & 0,130435 & 0,2 & 0,142857 & 0,157764 & 3,014698 \\
\hline & $\mathbf{1}$ & $\mathbf{1}$ & $\mathbf{1}$ & $\mathbf{1}$ & \\
CI & $=(\lambda$ maks-n)/(n-1) \\
& $=(4.014-3) /(3-1)$ \\
& $=0.005$ \\
RI & $=0.9$ \\
CR & $=$ CI / RI \\
& $=0.005 / 0.9$ \\
& $=0.008$ (konsisten)
\end{tabular}


g. Matriks Berpasangan Subkriteria Manajerial

Tabel 16. Matrik Berpasangan Subkriteria Manajerial

\begin{tabular}{|c|c|c|c|}
\hline & S10 & S11 & S12 \\
\hline S10 & 1 & 3 & 5 \\
\hline S11 & 0,333333 & 1 & 2 \\
\hline S12 & 0,2 & 0,5 & 1 \\
\hline Total & $\mathbf{1 , 5 3 3 3 3 3}$ & $\mathbf{4 , 5}$ & $\mathbf{8}$ \\
\hline
\end{tabular}

h. Menghitung nilai bobot prioritas (Manajerial)

Tabel 17. Nilai Bobot Prioritas

\begin{tabular}{|l|c|c|c|c|c|}
\hline & S10 & S11 & S12 & Bobot Prioritas & CM \\
\hline S10 & 0,652174 & 0,666667 & 0,625 & 0,647947 & 3,007145 \\
\hline S11 & 0,217391 & 0,222222 & 0,25 & 0,229871 & 3,002627 \\
\hline S12 & 0,130435 & 0,111111 & 0,125 & 0,122182 & 3,001318 \\
\hline & $\mathbf{1}$ & $\mathbf{1}$ & $\mathbf{1}$ & $\mathbf{1}$ & \\
\hline CI $\quad$ & $=(\lambda$ maks-n) / (n-1) \\
& $=(4.014-3) /(3-1)$ \\
& $=0.005$ \\
RI & $=0.9$ \\
CR & $=$ CI / RI \\
& $=0.005 / 0.9$ \\
& $=0.008$ (konsisten)
\end{tabular}

\subsection{Perhitungan FAHP}

Setelah diketahui nilai $\mathrm{CR}<0.1$, maka nilai perbandingan matriks berpasangan AHP (Tabel 7) diubah ke bentuk himpunan fuzzy segitiga atau Tringular Fuzzy. Langkah selanjutnya adalah penentuan nilai sistesis (SI), perhitungan nilai sintesis fuzzy mengarah pada perkiraan keseluruhan nilai masing-masing kriteria, subkriteria dan alternatif yang diinginkan.

\subsubsection{Matriks Perbandingan Berpasangan Kriteria FAHP}

Tabel 18. Matriks Perbandingan Berpasangan Kriteria FAHP

\begin{tabular}{|c|c|c|c|c|c|c|c|c|c|c|c|c|}
\hline & \multicolumn{4}{|c|}{$\mathrm{C} 1$} & \multicolumn{4}{c|}{$\mathrm{C} 2$} & \multicolumn{3}{c|}{$\mathrm{C} 3$} & \multicolumn{3}{c|}{$\mathrm{C} 4$} \\
\cline { 2 - 16 } & $\mathrm{l}$ & $\mathrm{m}$ & $\mathrm{u}$ & $\mathrm{l}$ & $\mathrm{m}$ & $\mathrm{u}$ & $\mathrm{l}$ & $\mathrm{m}$ & $\mathrm{u}$ & $\mathrm{l}$ & $\mathrm{m}$ & $\mathrm{u}$ \\
\hline $\mathrm{C} 1$ & 1 & 1 & 1 & $1 / 2$ & 1 & $3 / 2$ & $3 / 2$ & 2 & $5 / 2$ & $3 / 2$ & 2 & $5 / 2$ \\
\hline $\mathrm{C} 2$ & $2 / 3$ & 1 & 2 & 1 & 1 & 1 & 1 & $3 / 2$ & 2 & 1 & $3 / 2$ & 2 \\
\hline $\mathrm{C} 3$ & $2 / 5$ & $1 / 2$ & $2 / 3$ & $1 / 2$ & $2 / 3$ & 1 & 1 & 1 & 1 & $1 / 2$ & 1 & $3 / 2$ \\
\hline C4 & $2 / 5$ & $1 / 2$ & $2 / 3$ & $1 / 2$ & $2 / 3$ & 1 & $2 / 3$ & 1 & 2 & 1 & 1 & 1 \\
\hline
\end{tabular}


Citec Journal, Vol. 4, No. 1, November 2016 - Januari 2017

ISSN: 2460-4259

\subsection{2. $\quad$ Matriks Perbandingan Kriteria FAHP}

Pada matriks ini melalkukan penjumlahan pada baris setiap kolom sel, adapun hasilnya terlihat pada Tabel 19.

Tabel 19. Matriks Perbandingan Kriteria FAHP

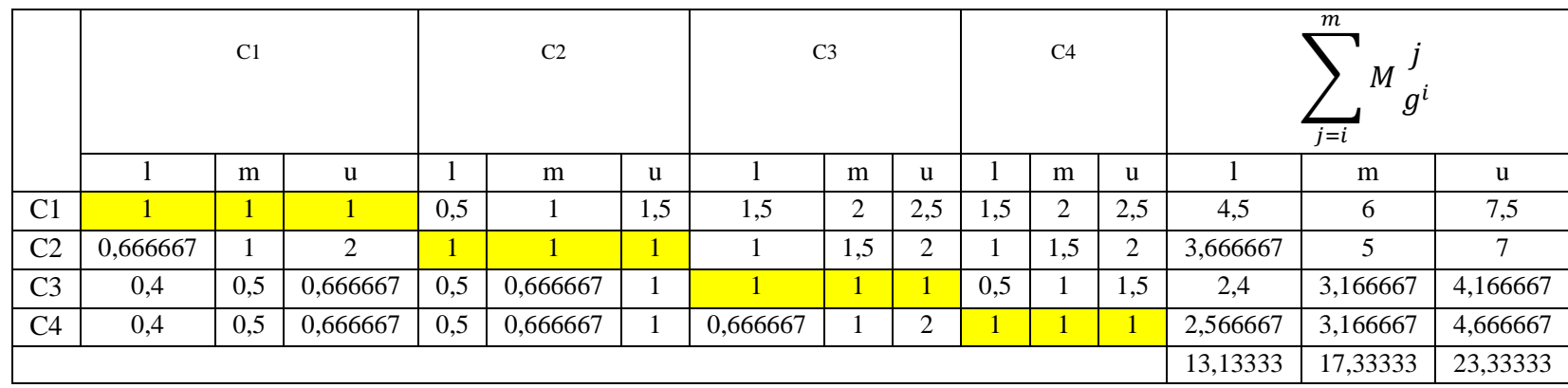

\subsubsection{Menentukan Nilai Sisteri Fuzzy (Si)}

$$
\begin{aligned}
S K 1 & =(4.5,6,7.5) \times\left(\frac{1}{23.33333}, \frac{1}{17.33333}, \frac{1}{13.13333}\right) \\
& =(0.192857,0.346154,0.571066) \\
S K 2 & =(3.666667,5,7) \times\left(\frac{1}{23.33333}, \frac{1}{17.33333}, \frac{1}{13.13333}\right) \\
& =(0.157,0.288,0.533) \\
S K ~ & =(2.4,3.166667,4,166667) \times\left(\frac{1}{23.33333}, \frac{1}{17.33333}, \frac{1}{13.13333}\right) \\
& =(0.103,0.183,0.317) \\
S K 4 & =(2,566667,3,166667,4,666667) \times\left(\frac{1}{23.33333}, \frac{1}{17.33333}, \frac{1}{13.13333}\right) \\
& =(0.11,0.183,0.355)
\end{aligned}
$$

\subsubsection{Kesimpulan Perhitungan nilai Sintesi Fuzzy (Si) Kriteria}

Tabel 20. Kesimpulan Perhitungan Nilai Sintesis Fuzzy (Si) Kriteria

\begin{tabular}{|c|c|c|c|}
\hline \multirow{2}{*}{ Kriteria } & \multicolumn{3}{|c|}{ Si } \\
\cline { 2 - 4 } & $\mathrm{l}$ & $\mathrm{m}$ & $\mathrm{U}$ \\
\hline C1 & 0,192857 & 0,346154 & 0,571066 \\
\hline C2 & 0,157143 & 0,288462 & 0,532995 \\
\hline C3 & 0,102857 & 0,182692 & 0,317259 \\
\hline C4 & 0,11 & 0,182692 & 0,35533 \\
\hline
\end{tabular}

\subsubsection{Kriteria Intelegensia (C1) dan nilai Vektornya}

Tabel 21. Nilai Vektor Kriteria Intelegensia

\begin{tabular}{|c|c|c|c|c|c|c|c|c|c|c|c|c|}
\hline & & 1 & lc1 & mc1 & uc1 & m & a & b & c & d & e & $d^{\prime}$ \\
\hline C1 & C2 & 0,157143 & 0,192857 & 0,346154 & 0,571066 & 0,288462 & $-0,41392$ & $-0,22491$ & 0,131319 & $-0,35623$ & 1,161952 & 1 \\
\hline C1 & C3 & 0,102857 & 0,192857 & 0,346154 & 0,571066 & 0,182692 & $-0,46821$ & $-0,22491$ & 0,079835 & $-0,30475$ & 1,536384 & 1 \\
\hline C1 & C4 & 0,11 & 0,192857 & 0,346154 & 0,571066 & 0,182692 & $-0,46107$ & $-0,22491$ & 0,072692 & $-0,2976$ & 1,549258 & 1 \\
\hline
\end{tabular}

$$
\begin{aligned}
& V C 1 \geq(V C 2, V C 3, V C 4) \\
& V C 1 \geq V C 2 \quad=\mathrm{m}_{1} \geq \mathrm{m}_{2} \\
& =0,346154 \geq 0,288462 \\
& =1 \\
& V C 1 \geq V C 3 \quad=\mathrm{m}_{1} \geq \mathrm{m}_{3} \\
& =0,346154 \geq 0,182692 \\
& =1
\end{aligned}
$$




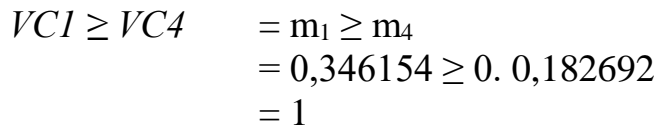

Sehingga diperoleh nilai ordinat, $d^{\prime}, d^{\prime}(V C 2)=\min (1,1,1)=1$

\subsubsection{Kriteria Kepribadian (C2), nilai Vektor}

Tabel 22. Nilai Vektor Kriteria Kepribadian

\begin{tabular}{|c|c|c|c|c|c|c|c|c|c|c|c|c|}
\hline & & 1 & lc2 & mc2 & uc2 & m & a & b & c & d & e & d' \\
\hline C2 & C1 & 0,192857 & 0,157143 & 0,288462 & 0,532995 & 0,346154 & $-0,34014$ & $-0,24453$ & 0,153297 & $-0,39783$ & 0,854983 & 0,854983 \\
\hline C2 & C3 & 0,102857 & 0,157143 & 0,288462 & 0,532995 & 0,182692 & $-0,43014$ & $-0,24453$ & 0,079835 & $-0,32437$ & 1,326077 & 1 \\
\hline C2 & C4 & 0,11 & 0,157143 & 0,288462 & 0,532995 & 0,182692 & $-0,42299$ & $-0,24453$ & 0,072692 & $-0,31723$ & 1,333419 & 1 \\
\hline
\end{tabular}

$$
\begin{aligned}
& V C 2 \geq(V C 1, V C 3, V C 4) \\
& C K 2 \geq V C 1 \quad=\frac{l_{1}-u_{2}}{\left(m_{2}-u_{2}\right)-\left(m_{1}-l_{1}\right)} \\
&=\frac{0,192857-0,532995}{(0,288462-0,532995)-(0,346154-0,192857)} \\
&=0,854983 \\
&=m_{2} \geq m_{3} \\
&=0.288462 \geq 0.182692 \\
&=1 \\
&=\mathrm{m}_{2} \geq \mathrm{m}_{4} \quad \text { Sehingga diperoleh nilai ordinat, } d, \\
&=0.288462 \geq 0.182692 d^{\prime}(V C 2)=\text { min }(0,854983,1,1)=0,854983 \\
&=1
\end{aligned}
$$

\subsubsection{Kriteria Sikap (C3), nilai Vektor}

Tabel 23. Nilai Vektor Kriteria Sikap

\begin{tabular}{|c|c|c|c|c|c|c|c|c|c|c|c|c|}
\hline & & 1 & lc2 & mc2 & uc2 & m & a & b & c & d & e & d' \\
\hline C3 & C1 & 0,192857 & 0,102857 & 0,182692 & 0,317259 & 0,346154 & $-0,1244$ & $-0,13457$ & 0,153297 & $-0,28786$ & 0,432156 & 0,432156 \\
\hline C3 & C2 & 0,157143 & 0,102857 & 0,182692 & 0,317259 & 0,288462 & $-0,16012$ & $-0,13457$ & 0,131319 & $-0,26589$ & 0,6022 & 0,6022 \\
\hline C3 & C4 & 0,11 & 0,102857 & 0,182692 & 0,317259 & 0,182692 & $-0,20726$ & $-0,13457$ & 0,072692 & $-0,20726$ & 1 & 1 \\
\hline
\end{tabular}

$$
\begin{aligned}
& V C 3 \geq(V C 1, V C 3, V C 4) \\
& V K 3 \geq V C 1 \quad=\frac{l_{1}-u_{2}}{\left(m_{2}-u_{2}\right)-\left(m_{1}-l_{1}\right)} \\
&=\frac{0,192857-0,317259}{(0,182692-0,317259)-(0,346154-0,192857)} \\
&=0,432156 \\
& V C 3 \geq V C 2=\frac{l_{1}-u_{2}}{\left(m_{2}-u_{2}\right)-\left(m_{1}-l_{1}\right)} \\
&=\frac{0,192857-0,317259}{(0,182692-0,317259)-(0,288462-0,192857)} \\
&=0,6022 \\
& V C 3 \geq V C 4=m_{3} \geq m_{4}
\end{aligned}
$$

Sehingga diperoleh nilai ordinat, $d^{\prime}=0,288462 \geq 0,182692$ $d^{\prime}($ VC3 $)=\min (0,432156,0,6022,1)=0,432156=1$ 
Citec Journal, Vol. 4, No. 1, November 2016 - Januari 2017

\subsubsection{Kriteria Manajerial (C4), Nilai Vektor}

Tabel 24. Nilai Vektor Kriteria Manajerial

\begin{tabular}{|c|c|c|c|c|c|c|c|c|c|c|c|c|}
\hline & & 1 & lc2 & mc2 & uc2 & m & a & b & c & d & e & d' \\
\hline C4 & C1 & 0,192857 & 0,11 & 0,182692 & 0,35533 & 0,346154 & $-0,16247$ & $-0,17264$ & 0,153297 & $-0,32593$ & 0,498483 & 0,498483 \\
\hline C4 & C2 & 0,157143 & 0,11 & 0,182692 & 0,35533 & 0,288462 & $-0,19819$ & $-0,17264$ & 0,131319 & $-0,30396$ & 0,652025 & 0,652025 \\
\hline C4 & C3 & 0,102857 & 0,11 & 0,182692 & 0,35533 & 0,182692 & $-0,25247$ & $-0,17264$ & 0,079835 & $-0,25247$ & 1 & 1 \\
\hline
\end{tabular}

$$
\begin{aligned}
V C 4 \geq(V C 1, V C 2, V C 3) \\
\begin{aligned}
C K 4 \geq V C 1 \quad & =\frac{l_{1}-u_{2}}{\left(m_{2}-u_{2}\right)-\left(m_{1}-l_{1}\right)} \\
& =\frac{0,192857-0,35533}{(0,182692-0,35533)-(0,346154-0,192857)} \\
& =0,498483 \\
V C 4 \geq V C 2 & =\frac{l_{1}-u_{2}}{\left(m_{2}-u_{2}\right)-\left(m_{1}-l_{1}\right)} \\
& =\frac{0,157143-0,317259}{(0,182692-0,317259)-(0,288462-0,157143)} \\
& =0,652025 \\
V C 4 \geq V C 3 & =\mathrm{m}_{4} \geq \mathrm{m}_{3}
\end{aligned}
\end{aligned}
$$

Sehingga diperoleh nilai ordinat, d' $=0,182692 \geq 0,182692$

$$
d^{\prime}(\text { VC2 })=\min (0,498483,0,652025,1)=0,498483=1
$$

Setelah mendapatkan nilai ordinat $\mathrm{C} 1, \mathrm{C} 2$, C3, dan C4, maka nilai bobot vektornya: $W^{\prime}=(1,0.854983,0.432156,0,498483)^{\mathrm{T}}$

\section{Menormalisasi bobot vektor:}

$W_{\text {lokal }}=(0.358986,0.306927,0.155138,0.178949)^{\mathrm{T}}$

Sehingga diperoleh nilai ordinat, $d$ '

$d^{\prime}($ VC2 $)=\min (1,1,1)=1$

a. Kriteria 2 (C2), dengan cara yang sama seperti kriteria 1 (C1) maka nilai vektornya adalah:

$$
\begin{array}{ll}
V C 2 \geq(V C 1, V C 3, V C 4) \\
V C 2 \geq V C 1 & =0.855 \\
V C 2 \geq V C 3 & =1 \\
V C 2 \geq V C 4 & =1
\end{array}
$$

Sehingga diperoleh nilai ordinat, $d$ ' $d^{\prime}(V C 2)=\min (0.855,1,1)=0.855$

b. Kriteria 3 (C3), dengan cara yang sama seperti kriteria 1 (C1) maka nilai vektornya adalah:

$$
V C 3 \geq(V C 1, V C 2, V C 4)
$$

$V C 3 \geq V C 1=0.432$

$V C 3 \geq V C 2=0.602$

$V C 3 \geq V C 4=1$

Sehingga diperoleh nilai ordinat, $d^{\prime}$

$d^{\prime}($ VC3 $)=\min (0.432,0.602,1)=0.432$

c. Kriteria 4 (C4), dengan cara yang sama seperti kriteria 1 (K1) maka nilai vektornya adalah:

$$
\begin{aligned}
V C 4 & \geq(V C 1, V C 2, V C 3) \\
V C 4 & \geq V C 1=0.498 \\
V C 4 & \geq V C 2=0.652 \\
V C 4 & \geq V C 3=1
\end{aligned}
$$

Sehingga diperoleh nilai ordinat, $d$ '

$$
d^{\prime}(\text { VSC4 })=\min (0.498,0.652,0.1)=0.498
$$


Berdasarkan nilai ordinat C1, C2, C3 dan C4, maka nilai bobot vektornya dapat ditentukan sebagai berikut:

$W^{\prime}=(1,0.855,0.432,0.498)^{\mathrm{T}}$

Setelah ditentukan nilai bobot vektor, maka langkah selanjutnya adalah menormalisasi nilai bobot vektor dimana tiap elemen bobot vektor dibagi jumlah bobot vektor itu sendiri. Dimana jumlah bobot yang telah dinormalisasi akan bernilai 1 . Normalisasi nilai bobot vektor fuzzy kriteria sama dengan nilai bobot prioritas global (yang menjadi tujuannya).

$W_{\text {lokal }}=(0.359,0.307,0.155,0.179)^{\mathrm{T}}$

$\sum W_{\text {lokal }}=1$

Sehingga bobot kriteria (lokal) yang diperoleh adalah 0.359, 0.307, 0.155, 0.179 . Penyelesaian perhitungan subkriteria dan alternatif sama seperti kriteria.

1. Perangkingan Alternatif Dan Hasil Keputusan

Nilai calon Ketua Osis periode 2015/2016 dapat dilihat pada Tabel 25.

Tabel 25 Nilai Calon Ketua OSIS Periode 2015/2016

\begin{tabular}{|c|c|c|c|c|c|c|c|c|c|c|c|c|}
\hline & \multicolumn{3}{|c|}{ Intelegensia } & \multicolumn{3}{|c|}{ Kepribadian } & \multicolumn{3}{|c|}{ Sikap } & \multicolumn{3}{|c|}{ Manajerial } \\
\hline & S01 & S02 & S03 & S04 & S05 & S06 & S07 & S08 & S09 & S10 & S11 & S12 \\
\hline & 0.539 & 0.297 & 0.164 & 0.608 & 0.272 & 0.12 & 0.655 & 0.187 & 0.158 & 0.648 & 0.23 & 0.122 \\
\hline Agatha & 85 & 80 & 79 & 85 & 78 & 80 & 77 & 85 & 80 & 90 & 85 & 84 \\
\hline Danang & 80 & 84 & 82 & 95 & 92 & 82 & 87 & 88 & 92 & 92 & 94 & 85 \\
\hline Fajar & 80 & 85 & 80 & 94 & 85 & 80 & 90 & 90 & 94 & 92 & 90 & 92 \\
\hline Mustofa & 85 & 95 & 90 & 85 & 90 & 92 & 88 & 87 & 78 & 90 & 85 & 95 \\
\hline
\end{tabular}

Setelah dilakukan perhitungan didapatkan hasil akhir berupa data calon ketua OSIS yang diurutkan berdasarkan nilai total terbanyak. Nilai total (alternatif) calon ketua OSIS dapat dilihat pada tabel 26.

Tabel 26. Hasil akhir perhitungan alternative

\begin{tabular}{|c|l|c|}
\hline Ranking & \multicolumn{1}{|c|}{ Nama } & Total \\
\hline 1 & Mustofa Nugroho & 29.342 \\
\hline 2 & Danang & 29.244 \\
\hline 3 & Fajar Andika & 29.093 \\
\hline 4 & Agatha & 27.656 \\
\hline
\end{tabular}

\section{KESIMPULAN}

Sistem pendukung keputusan yang telah dibuat dapat melakukan olah data alternatif (calon), kriteria, subkritera, nilai bobot alternatif, nilai bobot kriteria, nilai bobot subkriteria, perhitungan terhadap pengambilan keputusan, dan laporan hasil perhitungan.

Sistem pendukung keputusan pemilihan ketua OSIS ini memiliki output berupa laporan yang dapat dijadikan acuan Ketua MPK untuk memilih calon ketua yang berhak untuk diterima menjadi Ketua OSIS dan telah dapat melakukan perhitungan nilai Sintesis (Si), Nilai Vektor (V), Nilai Ordinat Defuzzifikasi (d'), Normalisasi Bobot Vektor (W), Analisa, dan Pemobobotan. Sehingga, setelah dilakukan perhitungan tersebut didapatkan perankingan dari alternatif calon OSIS. 
Citec Journal, Vol. 4, No. 1, November 2016 - Januari 2017

\section{SARAN}

Saran untuk penelitian selajutnya agar dibuat fitur restore dan backup database dengan cara menyimpan ke media penyimpanan yang lain.

\section{DAFTAR PUSTAKA}

[1] Turban, E., 2005, Decision Supporrt Systems and Intelligent Systems-7th Ed. Jilid 1, Andi Offset, Yogyakarta.

[2] Kusrini, 2007, Konsep dan Aplikasi Sistem Pendukung Keputusan, Andi Offset, Yogyakarta.

[3] Elveny, M., Rahmadsyah, 2014, Analisis Metode Fuzzy Analytic Hierarchy Process (FAHP) dalam Menentukan Posisi Jabatan, TECHSI Jurnal Penelitian Teknik Informatika, vol 4, no 1, hal 111-126.

[4] Anshori,Y., 2012, Pendekatan Triangular Fuzzy Number dalam Metode Analytic Hierarchy Process, Jurnal Ilmiah Foristek, vol 2, no. 1, hal 126-135.

[5] Jasril., Haerani, E., Afrianty, I., 2011, Sistem Pendukung Keputusan (SPK) Pemilihan Karyawan Terbaik Menggunakan Metode Fuzzy AHP (F-AHP), Seminar Nasional Aplikasi Teknologi Informasi 2011, Yogyakarta, 17-18 Juni 2011.

[6] Setyawan, B., Budianto, A. E., 2015, Sistem Pendukung Keputusan Penerimaan Calon Pengurus OSIS Menggunakan Metode Composite Performance Index (CPI) di SMPN 1 Kesamben, http://ejournal.unikama.ac.id/index.php/, diakses tanggal 11 Januari 2016. 